\title{
Weldability - Behavior of Welded Reinforcement
}

\author{
ANAMARIA FEIER ${ }^{1}$, OANA ROXANA CHIVU2*, AUGUSTIN STOICA ${ }^{3}$ \\ ${ }^{1}$ Politehnica University of Timisoara, Faculty of Mechanical Engineering, Department of Materials and Manufacturing Engineering, \\ 1 Mihai Viteazul Blvd., 300222, Timisoara, Romania \\ 2University Politehnica of Bucharest, Faculty of Engineering and Management of Technological Systems, 313 Splaiul Independentei, \\ 060021, Bucharest, Romania \\ ${ }^{3}$ E.ON Targu Mures,42 Pandurilor Blvd., 547176, Targu Mures, Romania
}

\begin{abstract}
Weldability involves two aspects: welding behavior of components and safety in operation. The two aspects will be reduced to the mechanical characteristics of the elements and to the chemical composition. In the case of steel reinforcing rebar's, it is reduces to the percentage of Cech(carbon equivalent) and to the mechanical characteristics: the yielding limit, the ultimate limit, and the elongations which after that represent the ductility class in which the re-bars is framed. The paper will present some types of steel reinforcing rebar's with its mechanical characteristics and the welding behavior of those elements. In the current work, process-related behavior of welded reinforcement, joint local and global mechanical properties, and their correlation with behavior of normal reinforcement and also the mechanical performance resulted in this type of joints.
\end{abstract}

Keywords: welding behavior, ultimate limit, reinforcing rebar's

Welding processes for reinforced concrete reinforcement shall be in accordance with Table 1 (Equivalent carbon value -according chemical composition of steel reinforcement rebar's) and the weldability shall be in accordance with EN 10080. The strength of welded meshes may be considered to be appropriate if each welding force can withstand shear strength of at least $25 \%$ force equal to the product of the feature specified yield strength and nominal cross-sectional area. It is recommended that this force be based on the area of thicker wire if the two are different.

The specific value of the Shear force of a welding point in a lattice girder case, $\mathrm{Fw}$, must be a minimum value. The minimum Fw must meet the following condition.

$$
F_{\mathrm{w}} \geq 0,6 \times R_{\mathrm{e}, \mathrm{Di}} \times A_{\mathrm{Di}}
$$

The understanding of process evolution is a key issue in welding and joining processes for behavior of welded reinforcement. This fundamental knowledge allows, for process optimization, a control of joint or welds mechanical properties. The influence of the joining process parameters on the final joint and its evolution have been widely explored in the literature [1-2]. This process had evaluated from the manual electrode process to today's mechanized processes (spot welding).

The examination of the welded reinforcement rebar's had been evaluated also from the Romanian Standards like as C 28/ 1983 to the European Standards like as ISO 15630-Steel for the reinforcement and prestressing of concrete - Test methods or EN ISO 17660-1: 2007, Welding of concrete steel. Part 1: Welded jointing loads.

\section{Experimental part}

\section{Materials and methods}

According to the standard SR EN 10080: 2006, Steels for reinforcing concrete, Welded reinforcement for reinforced concrete. Generalities (EN 10080: 2005) Weldability and chemical composition implies the following requirements:

- Weldability is determined by two characteristics: carbon equivalent; limits on the content of certain items.

- The maximum values of individual and carbon equivalents shall not exceed the values indicated in Table 2 (EN 10080: 2005).

-The equivalent carbon value should be calculated using the relation:

$$
C_{\text {eq }}=\mathrm{C}+\frac{\mathrm{Mn}}{6}+\frac{\mathrm{Cr}+\mathrm{Mo}+\mathrm{V}}{5}+\frac{\mathrm{Ni}+\mathrm{Cu}}{15}
$$

In the relation 2 the symbols of the chemical elements indicate the content in \% by mass.

NOTE - For recommendations on welding steels for reinforcing concrete, see prEN ISO 17660.

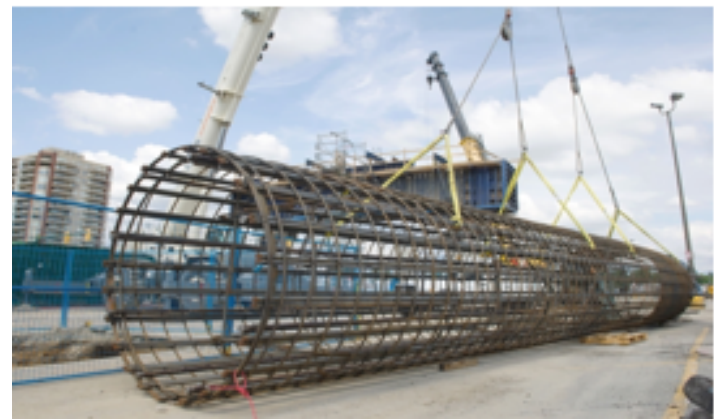

Fig 1. Welded reinforcement in the form of carcasses for pilots

\begin{tabular}{|c|c|c|c|c|c|c|}
\hline & Carbon & Sulf & Fosfor & Azot & Cupru & $\begin{array}{c}\text { Equivalent } \\
\text { carbon value }\end{array}$ \\
\hline $\begin{array}{c}\text { chemical } \\
\text { analysis of } \\
\text { liquid steel }\end{array}$ & 0.22 & 0.050 & 0.050 & 0.012 & 0.80 & 0.50 \\
\hline $\begin{array}{c}\text { chemical } \\
\text { analysis on } \\
\text { the product }\end{array}$ & 0.24 & 0.055 & 0.055 & 0.014 & 0.85 & 0.52 \\
\hline
\end{tabular}

Table 1

CHEMICAL COMPOSITION OF STEEL REINFORCEMENT REBAR'S

* email: virlan_oana@yahoo.co.uk 
By Decision of 5 December 2006, the European Commission withdrew the reference to EN 10080: 2005 from the list of European harmonized standards within the meaning of Directive 89/106/ EEC concerning construction products published in the Official J ournal of the European Union [3-5]. The regulatory application of this standard, which was due to enter into force on 1 February 2007, is therefore suspended; as a result, the prescriptions and / or provisions of this standard in relation to the CE marking cannot be applied.

-analysis had two reasons:

-EN 10080 does not take into account the Rm characteristic used in the regulation paraseismicã Italian

-Annex ZA to EN 10080 provides an indication of performance classes, but they are not defined in the text.

- The CE marking of the concrete steels is therefore postponed, pending the amendment of EN 10080, to take into account the objections of the European Commission.

- The entry into force of the Construction Products Regulation (RPC) does not change this state of affairs, EN 10080 cannot be considered as a harmonized technical specification.

\section{Results and discussions}

Test methods for reinforcement rebar's

In the literature, there are several standards that provide prescriptions for reinforcement testing, in this paragraph will be presented some of them.

According to SR CEN / TR 15481: 2015, Welding of reinforcing steel - Tack weldability - Test methods and performance requirements (CEN / TR 15481: 2006) Tests on concrete steel specimens are as follows:

-Tensile test according to EN ISO 15630-1 are recommended in case of the welded part of the specimen be located in the calibrated portion of the specimen.

-Are recommended to perform the bending test according to EN ISO 15630-1.

-Are recommended that the row of welding's be located outside the bending zone.

This Technical Report presents a method to verify the tack weldability of reinforcing steel. The purpose is to ensure that sufficient strength and ductility will remain in the welded material when short welding times are applied [6-9]. This Technical Report does not cover the welded joint itself.

According to SR EN ISO 17660-1: 2007, Welding of concrete steel. Part 1: Welded jointing loads (EN ISO 17660$1: 2006)$ are the following examinations and tests of the specimens:

- The specimens must be welded in accordance with the relevant welding procedure specification.

- All samples must be inspected visually before the test. In the case of welded steel welded joints made by electric arc welding methods, only specimens which have satisfied the surface level C level quality requirements, as appropriate, according to ISO 5817(Welding - Fusionwelded joints in steel, nickel, titanium and their alloys (beam welding excluded) - Quality levels for imperfections (ISO 5817:2014)), shall continue to be subjected to mechanical tests. For other procedures, the acceptance criteria apply according to the relevant standard for procedures. ISO 5817:2014 provides quality levels of imperfections in fusion-welded joints (except for beam welding) in all types of steel, nickel, titanium and their alloys. It applies to material thickness of $0.5 \mathrm{~mm}$. It covers fully penetrated butt welds and all filletwelds. Its principles can also be applied to partial-penetration butt welds. (Quality levels for beam welded joints in steel are presented in ISO 13919-1.) Three quality levels are given in order to permit application to a wide range of welded fabrication. They are designated by symbols $B, C$ and $D$. Quality level B corresponds to the highest requirement on the finished weld. Several types of loads are considered, e.g. static load, thermal load, corrosion load, pressure load. Additional guidance on fatigue loads is given. The quality levels refer to production and good workmanship. ISO 5817:2014 is applicable to non-alloy and alloy steels, nickel and nickel alloys, titanium and titanium alloys, manual, mechanized and automatic welding [10-11].

- All mechanical tests must be carried out in accordance with ISO 15630-1(Steel for the reinforcement and prestressing of concrete - Test methods - Part 1: Reinforcing bars, wire rod and wire) for tensile testing and bending test and in accordance with ISO 15630-2 for shear testing and bending tests, unless otherwise specified in 14.2 to 14.4. the standard SR EN 15630-2. ISO 15630-1:2010 specifies test methods applicable to reinforcing bars, wire rod and wire for concrete.

ISO 17660-1:2006 is applicable to the welding of weldable reinforcing steel and stainless reinforcing steel of load-bearing joints, in workshops or on site. It specifies requirements for materials, design and execution of welded joints, welding personnel, quality requirements, examination and testing. ISO 17660-1:2006 also covers welded joints between reinforcing steel bars and other steel components, such as connection devices and insert anchors, including prefabricated assemblies. Non loadbearing joints are covered by ISO 17660-2. ISO 176601:2006 is not applicable to factory production of welding fabric and lattice girders using multiple spot welding machines or multiple projection welding machines. The requirements of ISO 17660-1:2006 are only applicable to static loaded structures.

Destructive examinations of some reinforcement samples

In Romania in this moments the tests in the reinforcement are made acording EN ISO 15630-1 and EN 6892 , usually are required tensile tests and bending tests.

In the following study will be presented some tensile tests on Welded reinforcement rebar's and on lattice carcasses. The both type of specimens are welded reinforcement.

The reinforcementwere welded in accordance with the requirements of the C28 / 83 rebar's welding normative ( Romanian Normative).

The prescription of the Romanian Normative is: C;

-The heating temperature for artificial aging is $\mathrm{T}=100^{\circ}$

-Maintenance time for artificial aging. $\mathrm{T}$ (time) $=\mathrm{lh}$;

-The results obtained correspond to the Inspection Certificates; rebar tested has the mechanical characteristics of the PC 52 steel concrete according to SR 438-1: 2012. The elongation, the yielding and ultimate limit are in interval from standards. The failures have occurred in the base material, in reinforcement rebar it can be seen in the figure 2 .

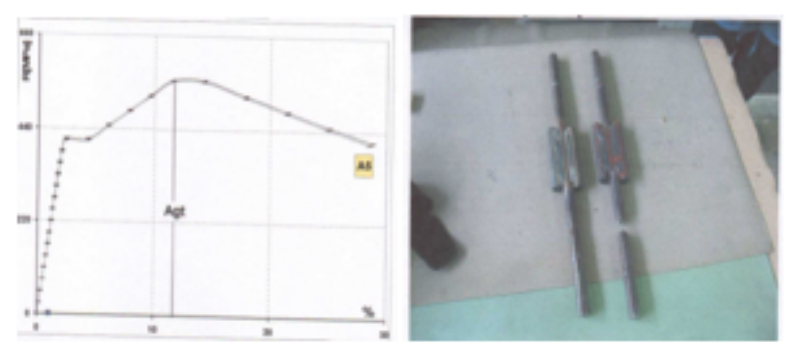

Fig 2. Welded reinforcement rebar's 

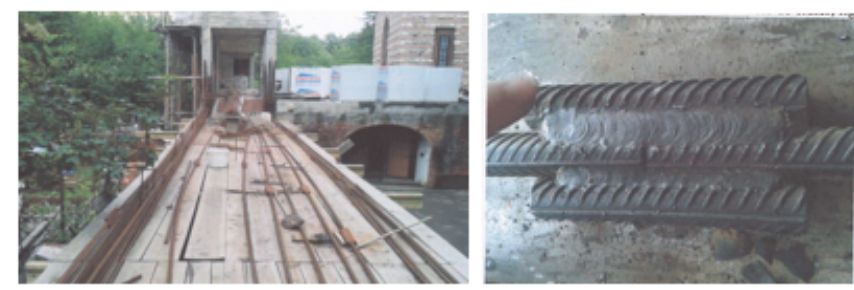

The Welded reinforcement rebar was used in a rehabilitation of a historical building and the expert of the project wants that in the project the welded reinforcement to have an execution class in accordance with EN 1090. Execution class EXC3 was needed, because the building is historical according EN 1090.

The specimens used in rehabilitation of the historical building from the figure 3 had been also examinated according the Romanian Standards. The specimens had been take on the site and the failure have occurred in the base material and in conclusion the welded joint wad made in good condition and in good parameters.

\section{UNIFIL B450C lattice carcasses}

This type of reinforcement are especially used for reinforced concrete or prestressed concrete elements made with prefabricated and over-concrete prefabricated precincts on site, bridge bridges, floor beams, bridge bridges, beams for filler floors.

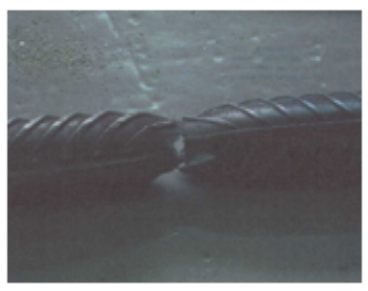

Fig 3. Welded reinforcement rebar's used at the rehabilitation of a historical building

With the following geometric characteristics:

$L: \pm 40 \mathrm{~mm}$ for $L \leq 5.0 \mathrm{~m} ; \pm 0.8 \%$ for $L>5.0 \mathrm{~m}$. H1, H2: $\pm 1 /-3 \mathrm{~mm}$

B1: $\pm 7.5 \mathrm{~mm}, \mathrm{Ps}: \pm 2.5 \mathrm{~mm}$

This type of reinforcement are made in Italia and now on the market of Romania are with Technical Agreement, because this type of reinforcementare notunder incidence of SR 438:2012.

UNIFIL B450C lattice carcasses are used to produce self-supporting plates in order to create bridges decks, multilevel car parks, multistory buildings and harbor docks.

Standard lattice girder is widely used in prefabricated building industry. This scaffolding is produced by welding two lower longitudinal steel bars and an upper longitudinal steel bar connected through welded stirrups, and itis used for producing panels and walls and civil buildings. In the table below are listed all nominal characteristics of standard lattice girder.

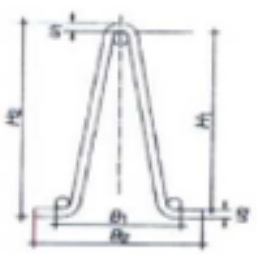

nomien
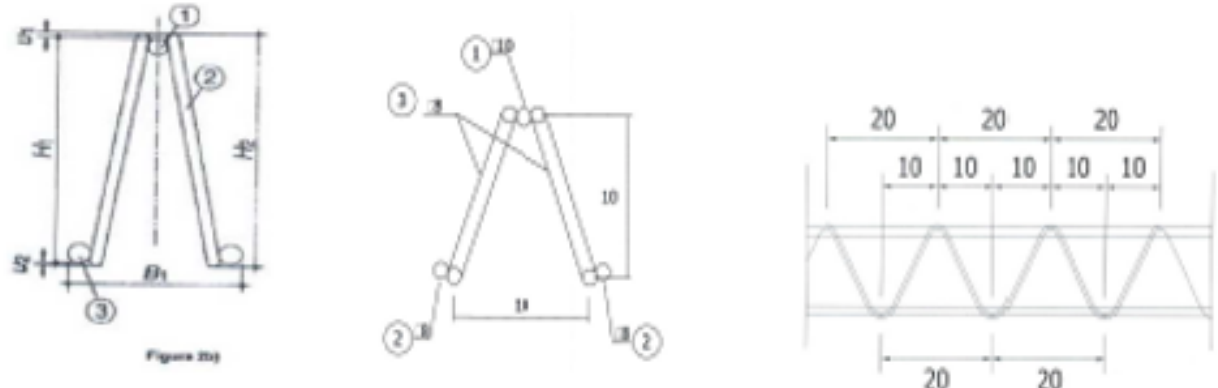

Fig 4. Lattice carcasses geometric characteristically:1-top chord; 2-diagonal, 3-bottom chord, H1- height of carcass calculation, H2-total height of lattice carcass, B1- width of carcass, ì1, ì2- length of heads, Ps- diagonal pitch, angle of inclination of diagonals; L-length of the lattice.

Table 2

CHEMICAL COMPOSITION OF UNIFIL B450C LATTICE CARCASSES

\begin{tabular}{|c|c|c|c|c|c|c|c|c|c|}
\hline & C & $\mathrm{Si}$ & Mn & $\mathrm{s}$ & $\mathrm{Cr}$ & Mo & $\mathrm{Cu}$ & $\mathbf{P}$ & $\mathrm{Ceq}$ \\
\hline $\begin{array}{l}\text { chemical } \\
\text { analysis } \\
\text { on the } \\
\text { product }\end{array}$ & $0.20-0.22$ & $\begin{array}{l}0.23- \\
0.28\end{array}$ & $0.8-1.0$ & $\begin{array}{l}0.03- \\
0.04\end{array}$ & $\begin{array}{l}0.08- \\
0.15\end{array}$ & $\begin{array}{l}0.04- \\
0.05\end{array}$ & $\begin{array}{l}0.40- \\
0.05\end{array}$ & $0.02-0.03$ & $=0.5$ \\
\hline
\end{tabular}
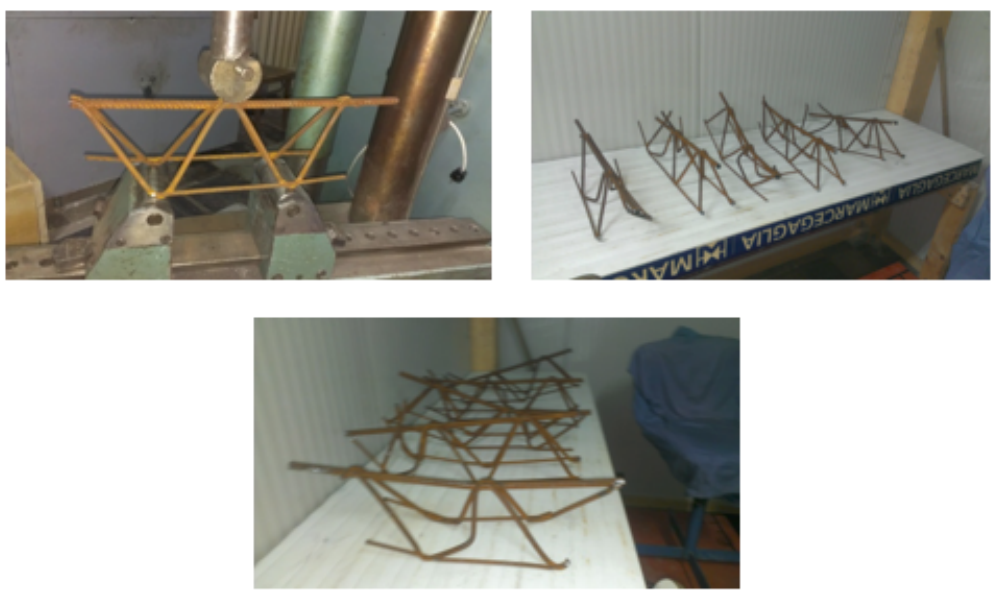

Fig 5. Destructive examinations - UNIFIL B450C lattice 


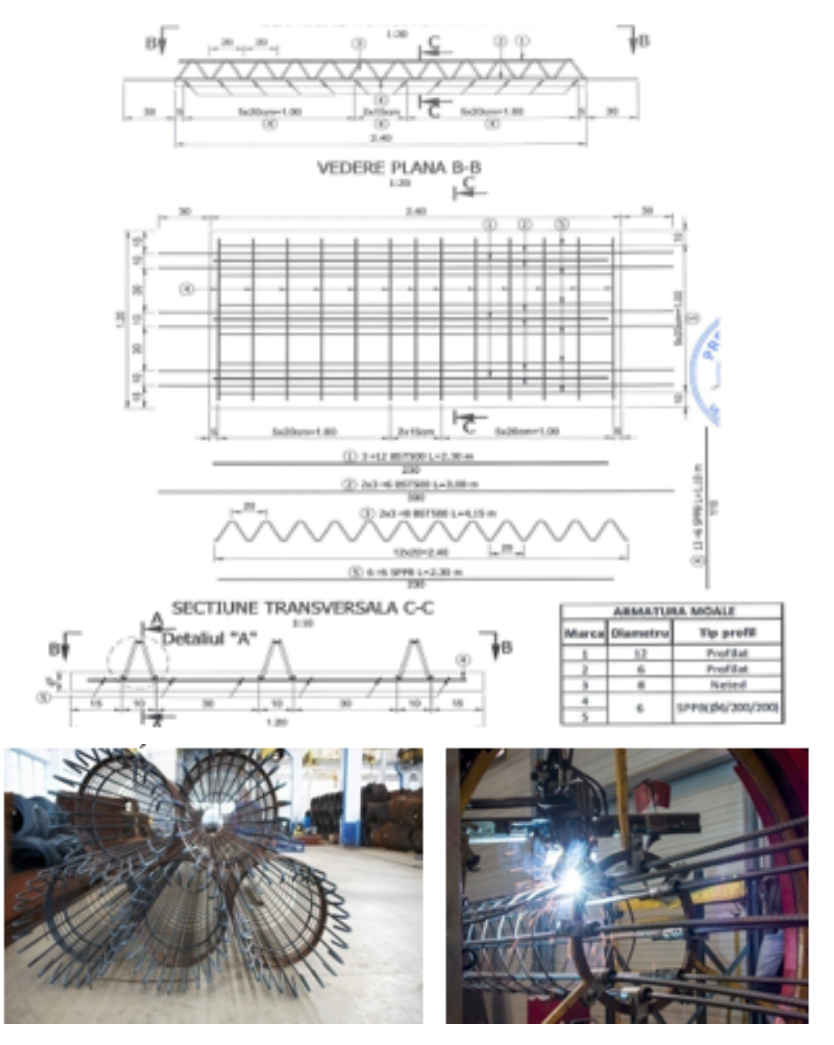

Spot welding of reinforcement bars

Spot welding is a process for pressure welding in which welding occurs between the faces of two pieces, close contact between the electrodes through which the welding current directed perpendicular to the faces of the parts to be welded.

Scope: spot welding is used for making nets and welded carcasses used as reinforcements in concrete, made of crossbars joined by welded joints.

Terms of use. Can be joined by spot welding process, wherein the ratio of the diameters of the bars to satisfy the condition: when at least one of the bars is of hardened steel (something like: STNB or STNB).

\section{Conclusions}

The study cover only the usual reinforcement rebars and some type of standard lattice girder is widely used in prefabricated building industry but is very important that the examination of this type needed to be according standards that are valid, for example ISO 17660-1:2006 is not applicable to factory production of welding fabric and lattice girders using multiple spot welding machines or multiple projection welding machines. The requirements of ISO 17660-1:2006 are only applicable to static loaded structures.

The way of welding of the reinforcement rebar will be needed to be specified in the project, together with any specific conditions, as well as with the admissible deviations. Execution of welding devices, including the qualification of welders, as well as checking the quality of the welds (admissible deviations, admissible defects, etc.) will be done according to the provisions of the specific technical regulations.

The following should be considered:

- no welds should be made on the bent areas of the reinforcement rebar, and the provisions of the applicable technical regulations should be observed in the vicinity;

- welding is not allowed to mechanically improved steel reinforcements (eg by cold drawing), except for welded mesh;

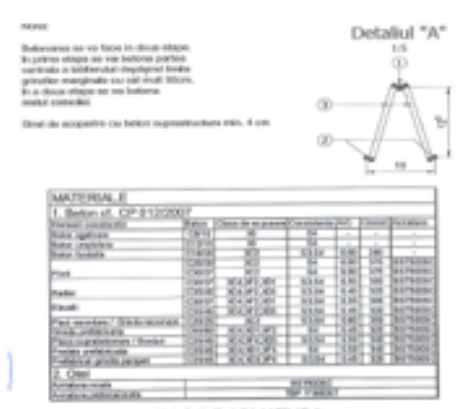

Fig 6. Longitudinal section from a bridge - UNIFIL B450C lattice

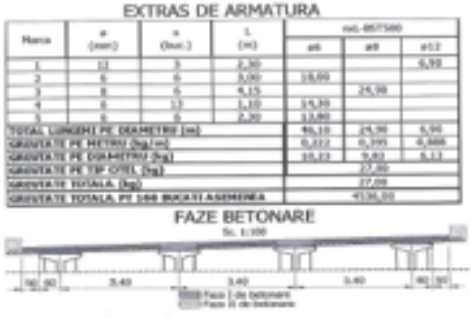

Fig 7. Welded reinforcement for carcasses

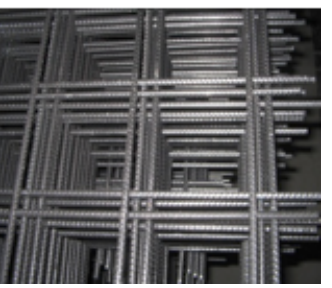

- the designer's approval will be required for welding conditions of continuity between two reinforcement rebar anchored to one side of a concrete slab, located relatively distant from each other.

Bending of reinforcing rebar can be done by other methods, only with the designer's approval, which will also provide for specific conditions, as the case may be:

- Verification and reception of all armature

- At the end of the assembly works, for a working stage, when the works are also accepted;

- Immediately before the concrete is put into operation when a new check is made.

\section{References}

1.CHIVU, O., Metalurgija,Vol.52,no.4,2013,p. 465-468

2.FEIER,A.,CHIVU,O., Rev.Chim.(Bucharest), 69, no. 6 , 2018, p 13521354

3.SZYMANIK, B.; FRANKOWSKI, P.K.; CHADY, T.; J OHN CHELLIAH, C.R.A.. Sensors, 2016, 16, p234.

4.FEIER,A.,DUMBRAVA,D.,CHIVU,O., BABIS,C., DIMITRESCU,A., , Fiabilitate si Durabilitate - Fiability \& Durability No 1, 2018,p 76-79 5.HASAN, M.I.; YAZDANI, N. Case Stud. Construct. Mater. 2014, 1, p104114

6.HO£A, J.; SCHABOWICZ, K.. Arch. Civil Mech. Eng. 2010, 10,p 5-18 7.FEIER,A., DUMBRAVA,D., BURCA,M., CHIVU, O., BABIS,C., DIMITRESCU,A., Fiabilitate si Durabilitate - Fiability \& Durability No $\mathbf{1}$, 2018 p 71-75

8. BABIS,C., SEMENESCU,A.,CHIVU,O., GLIGOR,A., IACOBESCU,G., GHIMISI,S., NEGOITA,O.,Rev.Chim. (Bucharest) ,69, no. 7,2018, p.18261829

9.SCHWALIE,A., FEIER, A., HERNEA, S., BANCILA, R., Procedia Engineering, no156,p419-426

10.SCHWALIE, A., PETZEK,E., FEIER, A., BANCILA, R., Procedia Engineering, no156,p435-442

11.JIANG, J.-Y.; LIU, Y.; CHU, H.-Y.; WANG, D.; MA, H.; SUN, W. ,Materials 2017, 10, p903

Manuscript received: 21.12 .2018 